\title{
Civilian gunshot wounds of the spine: A literature review
}

\author{
AOSpine Spine fellow, University of Cape Town \\ Dr BC Booysen MBChB(UFS) Kimberley Hospital Complex \\ Prof RN Dunn MBChB(UCT), MMed(UCT), FCS(SA)Orth \\ Correspondence \\ Dr AH Botha \\ Suite 202 Paardevlei Private Hospital \\ 4 Gardner Williams Avenue \\ 7130 Somerset West \\ Email: attie@spinalclinic.co.za \\ Tel: 0218406697
}

Dr AH Botha MBChB(Stell), MMed Ortho(Stell), FCS Ortho(SA)

Pieter Moll and Nuffield Chair of Orthopaedic Surgery, University of Cape Town

\begin{abstract}
The incidence of gun-related violence continues to rise, although accurate statistics are difficult to obtain. Up to $17 \%$ of spinal cord injuries are gunshot related. The recent literature pertains to the management of high velocity/energy gunshot wounds as encountered in war scenarios such as Iraq, Afghanistan, etc.

The treatment of civilian gunshot wound injuries to the spine has not been clearly stipulated, and many treatment modalities are adopted from the treatment of war injuries, which is a completely different scenario.

Aim: To evaluate the available literature pertaining to civilian gunshot wound injuries of the spine and the treatment thereof with regard to the indication for bullet removal, antibiotic prophylaxis, lead poisoning, the use of imaging modalities and fracture stability.

Conclusion: Although the literature is often conflicting and published case series are outdated, there is consensus that not all bullets or fragments need to be removed; the majority of fractures are stable; MRI is a safe imaging modality; lead poisoning is extremely rare; and extended antibiotics prophylaxis is not needed.

The indications for bullet removal is deteriorating neurology, intra-canal bullets between T12 and L4 with incomplete neurology, sepsis and lead poisoning should it occur.
\end{abstract}

Key words: gunshot, spinal injury, neurology, spinal column, lead

http:/ / dx.doi.org/10.17159/2309-8309/2016/v15n3a1

\section{Introduction}

Gunshot wounds continue to be one of the most common causes of injuries in South Africa. This is due to the large circulation of illegal firearms, and firearms stolen or lost from the South African Police Service and the South African National Defence Force. It has been reported that the SAPS have 'lost' 20429 weapons since April 2004.

There has been a dramatic rise in the incidence of gunshot injuries, as reported by Saadia. ${ }^{2}$ In 1988 there was 988 gunshot wound injuries reported at Chris Hani Baragwanath Hospital, and this rose to 3152 cases per year by $1998 .{ }^{2}$ Groote Schuur Hospital reported between 70 and 120 gunshot injuries per month in 2005. Prince Mshyeni Hospital reported 78 abdominal gunshot wounds between January 2005 and June $2005 .{ }^{4}$

In the United States, gunshot injuries to the spine account for $13-17 \%$ of all spinal cord injuries.

Anecdotal evidence suggests that this trend has continued, but accurate modern-day statistics are difficult to obtain. Gunshot wounds to the spinal column with associated neurological injury account for a large proportion of these injures, leading to increased morbidity and mortality, as well as the need for allocation of extensive resources. Dunn and Le Roux reported an average hospital stay of 30 days for patients with spinal gunshot wounds. ${ }^{3}$ Carrillo et al. reported an average length of stay of 58-85 days when in-patient rehabilitation was included, with an average cost of \$87 750-\$142 710. ${ }^{5}$

Demographics of spinal gunshot injuries follow a similar pattern internationally, with most patients being males between the ages of 15 and 34 years. ${ }^{3,6-9}$ Most of these are also complete spinal cord injuries. . $^{3,10,11}$

The vast majority of these injuries do not occur in isolation. Dunn et al. reported in their series of 49 patients that there were 55 associated injuries including haemopneumothoraces, intra-abdominal injuries, vascular injuries, etc. ${ }^{3}$ 
Treatment of gunshot injuries of the spinal column is controversial. The majority of studies published regarding civilian gunshot wounds are from the 1980s and 1990s. ${ }^{12-24}$ Recent literature is mostly restricted to military gunshot injuries, which is more of the high velocity/energy type of injuries. $^{25-33}$

\section{History of treatment}

When Lord Nelson sustained a spinal cord injury from a gunshot at the Battle of Trafalgar his personal surgeon told him, 'My Lord, unhappily for our country, nothing can be done for you'. Nelson died a few hours later. ${ }^{34}$

The treatment of spinal cord injury and gunshot wounds has improved markedly in the last century, although much of the literature pertains to military or high energy gunshot wounds.

The principles of treatment for military gunshot wounds of the spine entail debridement of all contaminated tissue along the tract and removal of bony and bullet fragments from the spinal canal, closure of dural defects to prevent fistulas and surgical decompression of the spinal cord. ${ }^{35,36}$

Civilian or low energy gunshot wounds are a completely different entity, and the same treatment rationale cannot be used. However, many still believe in the treatment principles as stipulated above.

\section{Gunshot ballistics}

Traditionally gunshot wounds have been classified as either low $(<2000 \mathrm{ft} / \mathrm{sec})$ or high velocity $(>2000 \mathrm{ft} / \mathrm{sec})$. Recent trends have tried to classify gunshot injuries as either high or low energy. ${ }^{37}$

A shotgun is classified as a low velocity weapon, but extreme amounts of energy transfer occur resulting in extensive soft tissue damage.

The energy of the bullet is influenced both by the mass of the bullet, as well as the speed at which it travels. This is reflected in the formula $K E=0.5 m v^{2}$ where $K E$ is the kinetic energy, $m$ the mass of the projectile and $v$ the velocity. Other factors that play a role are stability of the bullet, entry profile, path travelled through the body and the tissues encountered.

A $9 \mathrm{~mm}$ bullet of 115 grain weight has $401 \mathrm{ft} /$ pound muzzle energy when it leaves the barrel. This is significantly less than an M16 $5.56 \mathrm{~mm}$ round with $1297 \mathrm{ft} /$ pound muzzle energy. A 12-gauge shotgun firing a slug has $2604 \mathrm{ft} /$ pound muzzle energy, although the velocity is only $1180 \mathrm{ft} / \mathrm{sec}$, classifying it as a low velocity weapon (Figure 1).

The transfer of energy is another important factor to consider, and this is where bullet design and entry profile play a key role. Full metal jacket rounds are designed to maintain the maximum amount of energy, and very little energy is transferred to the soft tissue, unless the bullet strikes bone. If the bullet strikes tissue with a yaw it will tumble and cause greater energy transfer and tissue damage.
Hollow point ammunition is designed to fragment and transfer as much possible energy to the soft tissue, causing maximal soft tissue damage and transfer of energy.

Traditionally bullet design consisted of a lead core and a copper jacket, although newer designs of an 'environmentally friendly' bullet consist of a copper only design.

\section{Clinical evaluation}

It is important to note that gunshot spinal injuries rarely occur in isolation. There is a high incidence of associated injuries, with figures ranging from $79-280 \%{ }^{3,538}$ (Figure 2). $\mathrm{Up}$ to $65 \%$ of these injuries require surgical intervention, and the vast majority are abdominal injuries $(31 \%))^{5,38}$

It is therefore of utmost importance to evaluate these patients along with other specialities according to ATLS principles, and not to see the spinal gunshot injury as an isolated entity.

\section{Imaging}

Entry and exit wounds should be covered with a sterile dressing, and radiopaque markers applied over the dressing, such as an ECG sticker. This will enable identification of the tract of the bullet, and will indicate the imaging modalities needed to diagnose suspected associated injuries.

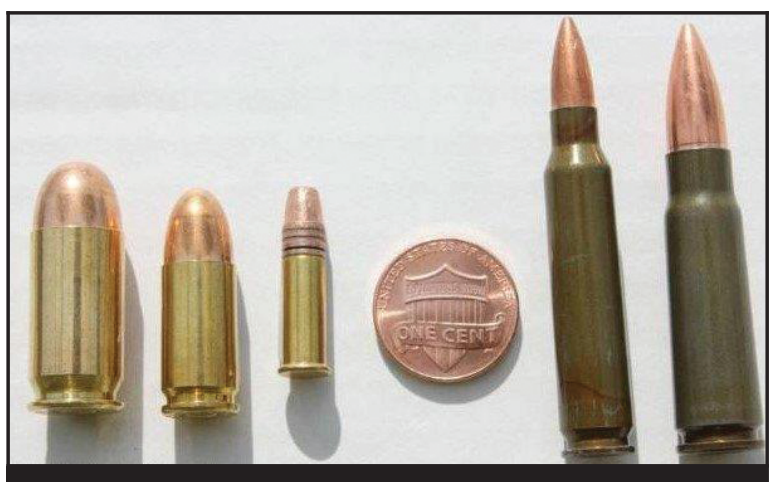

Figure 1. A10 mm, 9 mm, 22 LR, $5.56 \mathrm{~mm}$ and AK47 round

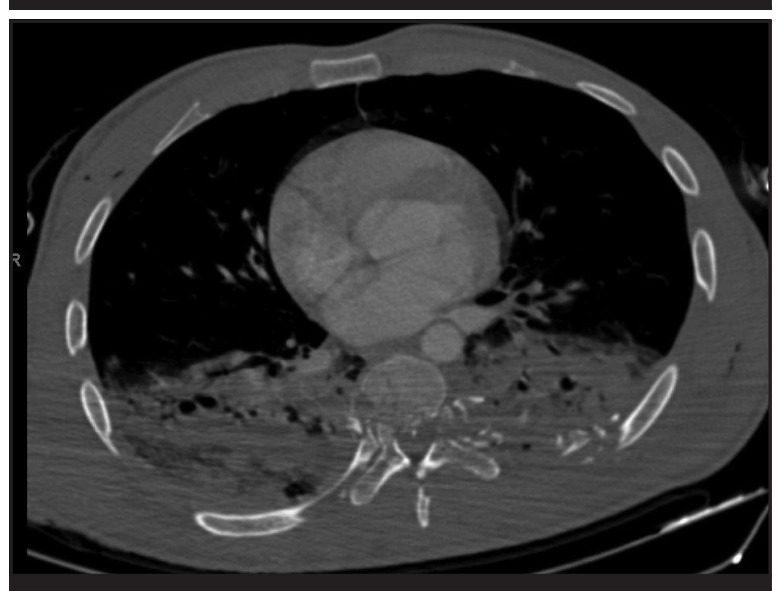

Figure 2. Bullet traversing the chest cavity and spine 
With regard to the spine it is important to obtain orthogonal views of the area affected. Standard imaging modalities should be supplemented with CT scan if visualisation of the affected structures is poor.

CT scan of the affected spinal area is often necessary to ascertain whether the injury pattern is stable or not (Figure 3).

Magnetic resonance imaging of the spinal column with retained bullet fragments remains a controversial subject. Shrapnel migration and the heating of residual fragments are the main concern. Previous studies have confirmed the safety of MRI scanning in patients with retained non-ferrous bullet fragments in 1.5 Tesla magnets..$^{39-42}$

Dedini et al. showed that MR imaging of the spine with retained bullet fragments is safe, even up to 7 Tesla. $^{43}$ Fragment migration was not a concern.

The maximum temperature increase of the retained fragments was $1.7^{\circ} \mathrm{C}$, compared to background heating of tissue of $1.5^{\circ} \mathrm{C}$. This was not statistically significant.

Stainless steel is only found in pellets and certain military ammunition, and should not be of concern in civilian gunshot injuries, unless the projectile originates from a pellet gun or shotgun.

\section{Lead toxicity}

Debate over lead and copper toxicity continues, but lead toxicity is more common when bullets are bathed in synovial fluid. There are but a few case reports on lead toxicity with bullets or fragments in the spinal canal surrounded by cerebrospinal fluid, or from bullets in the disc space $^{44.49}$ (Figure 4).

Given the prevalence of gunshot wound injuries of the spine and the low incidence of lead toxicity of bullet fragments in contact with cerebrospinal fluid, lead toxicity should not be a concern or a reason for removal of the bullet.

Lead poisoning can present with hypertension, abdominal cramping, constipation, joint and muscle pain, headache and mood disorders. The treatment of lead poisoning is to first remove the source, and to treat the patient with chelation therapy that binds and excretes the lead.

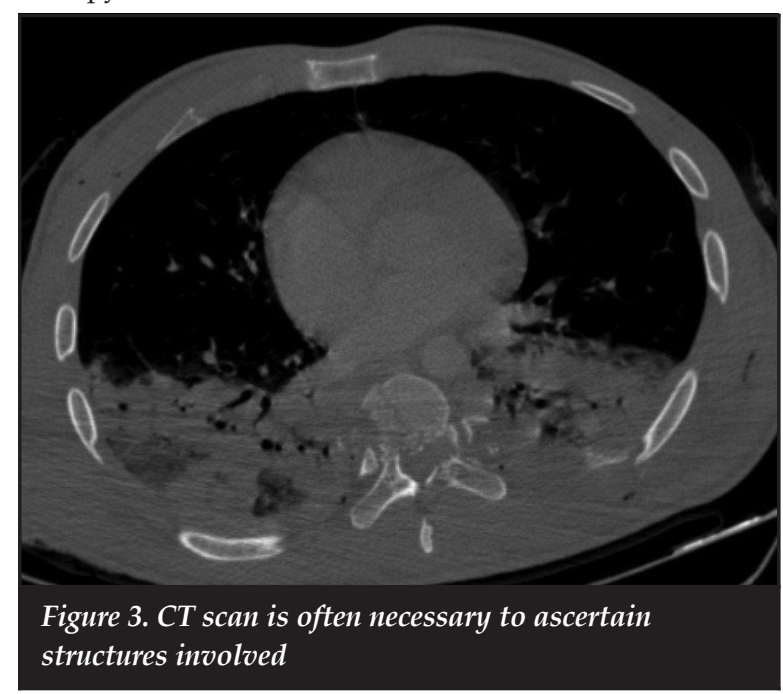

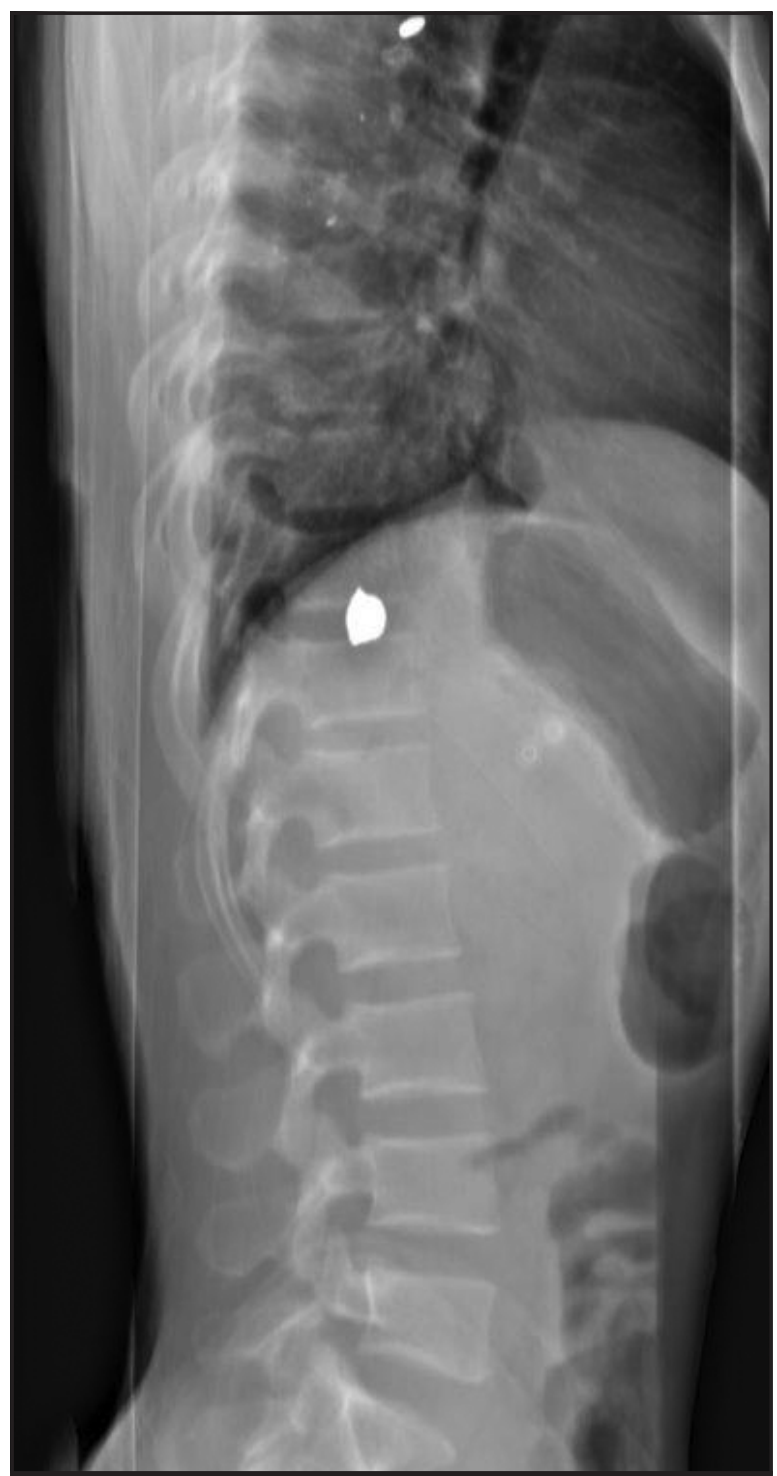

Figure 4. Bullet in the intervertebral disc

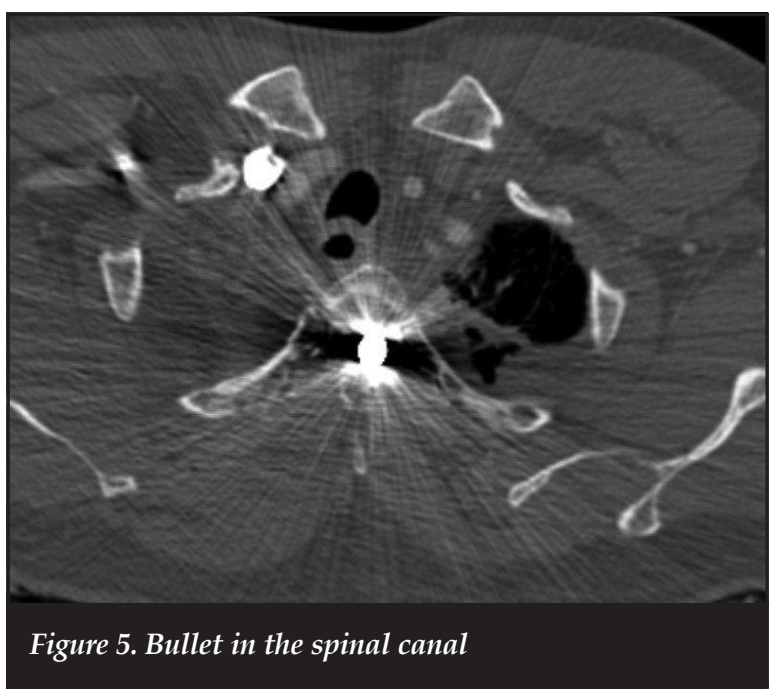


In-vivo experiments have demonstrated necrotic effect of copper fragments on neural tissue. Tindel $e t$ al. in a rabbit model demonstrated spinal cord necrosis around implanted bullet fragments beneath the dura; however, extra-dural bullet fragments did not result in any neural necrosis. ${ }^{46}$

These results could be extrapolated to human neural tissue, but it is often difficult to ascertain the nature of the fragment material, and the complications of intra-dural bullet removal can result in further neurological deterioration and complications (Figure 5).

\section{Fracture stability}

Most fracture classification systems for spinal column trauma describe the direction of the indirect force applied to the bony and ligamentous structures of the spinal column. Gunshot wounds to the spinal structures are a directional and direct force, and hence classification systems cannot describe and help with the identification of unstable fractures. Even three-column injuries can still be stable in the low energy gunshot scenario.

The vast majority of gunshot injuries to the spinal column are stable injuries, with the ligaments and bony structures left intact, except for the areas that the bullet traversed..$^{38}$

Any degree of angulation or listhesis should be further evaluated for instability with flexion and extension radiographs.

If the bullet traversed both pedicles in the coronal plane, there is a risk of instability, and dynamic investigations should be performed. However, in the vast majority of cases, instability occurs secondary to decompression surgery. ${ }^{15}$

\section{Neurological injury}

Neurological injury is common, and the majority of injuries occur at the thoracic level (Figure 6) with 25-59\% resulting in complete spinal cord injuries..$^{511,38}$ There is a high risk of complete injury with thoracic gunshot wounds when compared to gunshot wounds to the other areas of the spinal column.

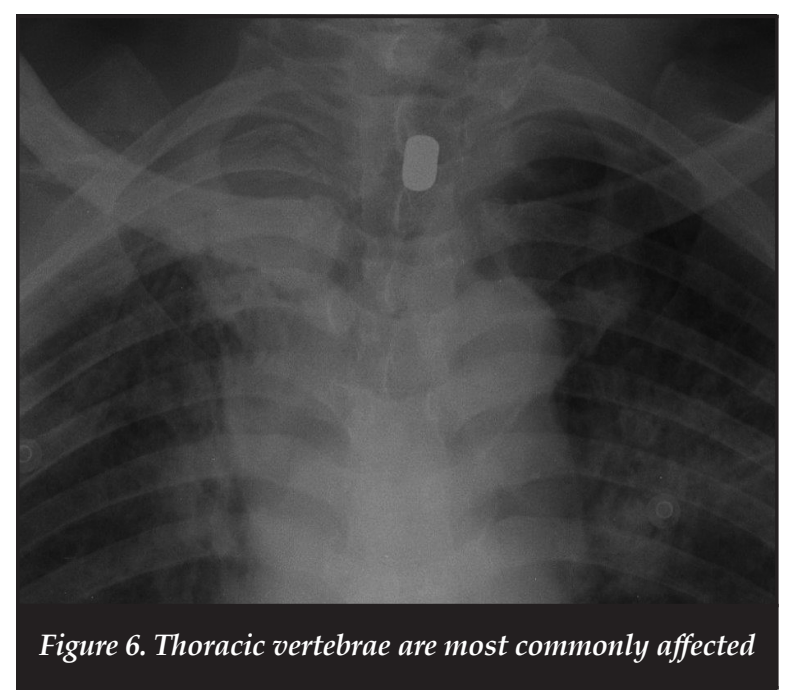

The administration of steroids for patients with neurological deficit has also been studied, and no benefit was found. ${ }^{50,51}$ Administration of methylprednisolone had a high incidence of pancreatitis, while dexamethasone had the highest GIT complication rate. ${ }^{51}$

Heiden et al. reported that the outcome and potential for recovery depended on the initial injury, and that surgical intervention did not alter neurological outcome, in either complete or incomplete patients. ${ }^{13}$ This still holds true today, except for patients with incomplete neurology with retained bullet fragments between T12 and L4 in the region of the cauda equina.

\section{Removal of spinal column bullet fragments}

Various studies have been performed to assess the impact of removal of bullet fragments in the spinal column and the improvement of neurology. $13,17,18,24,3,5,52-56$

The available evidence clearly shows that improvement in neurological status may occur only after removal of retained bullet fragments between the levels of T12 and L4 in patients with incomplete neurological deficit. ${ }^{52}$ This study by Waters et al. showed no improvement in neurological status at any other level, regardless of it being a complete or an incomplete injury. They also reported a high complication rate associated with surgical removal of the retained fragments.

Stauffer et al. also found no benefit with regard to neurological improvement when bullet fragments were removed in their study. In contrast to Waters et al. they found no benefit when bullet fragments were removed from the lumbar spine. Complications from surgery were also high in Stauffer's study, ranging from sepsis and CSF leaks postoperatively to late instability. Robertson and Simpson also found no benefit from removing bullet fragments, but again reported a high complication rate from surgery. ${ }^{57}$ Their study reported four wound infections, six spinal fistulae and six cases of late spinal instability.

From the literature, the only indications for removal of retained bullet fragments would be: progressive neurological deterioration, sepsis, lead poisoning and retained fragments between T12 and L4 with incomplete neurological injury.

\section{Antibiotics and wound management}

Tetanus prophylaxis should be administered in all spinal gunshot injuries if there is doubt with regard to previous tetanus immunisations. Broad spectrum antibiotics should be administered, but the duration of administration should be guided by the amount of soft tissue damage. If there is no evidence of viscus perforation, 48-72 hours should be sufficient.

Antibiotic treatment of gunshot wounds traversing the gastrointestinal tract into the spine remains a widely debated topic, with proponents for both short course therapy as well as extended administration. 
Romanick et al. published their study in 1985 where patients with transvisceral injuries were treated with antibiotics for a period of between 2 and 14 days. ${ }^{58} \mathrm{~A}$ total of $87.5 \%$ of their patients developed spinal or paraspinal infections. Some of these infections presented only after 11 weeks, even in those patients who had antibiotic therapy extended beyond 5 days. Romanick concluded that patients with transvisceral injuries should be monitored closely for the development of delayed sepsis, even when treated with extended periods of antibiotics.

In 1989 Roffi et al. published a lower rate of spinal or paraspinal infections with only three of 42 developing infection. These three patients had prophylactic antibiotics for 6,14 and 14 days respectively. However no mention was made of resistance or adverse events. ${ }^{22}$

Kihtir et al. used a short course of antibiotic prophylaxis of 48 hours along with appropriate intra-abdominal injury treatment and irrigation of the missile tract in 21 patients with transvisceral spinal gunshot injuries. They reported no spinal or paraspinal injuries. ${ }^{59}$

Lin et al. treated 29 patients with only 48 hours of prophylactic antibiotics, and only two patients developed paraspinal infections in the form of psoas abscesses. ${ }^{60}$

Kumar et al. reported no spinal infection in their series of 13 patients with trans-colonic injuries who were treated with 7 days of prophylactic antibiotics. ${ }^{61}$

Rabinowitz et al. published their retrospective review of 51 patients with trans-visceral injuries in 2012.62 Only one patient developed a spinal or paraspinal infection. The majority of patients in the study received 48 hours of prophylactic antibiotics in the form of a second generation cephalosporin, while some received a combination of ampicillin/sulbactam, piperacillin/tazobactam and clindamycin. Thirty-three of the 51 patients did develop non-spinal infections and required further appropriate antibiotic treatment. The patient that developed spinal sepsis did so after two weeks of piperacillin/tazobactam treatment for a bacteraemia. ${ }^{62}$

In all of the abovementioned studies it was not deemed necessary to remove retained fragments. Missile tracts were not routinely irrigated in any of the studies, with no associated risk of developing spinal sepsis.

Should laparotomy be indicated for intra-abdominal injury, it is advisable to irrigate the missile tract.

\section{Conclusion}

Civilian gunshot injuries to the spinal column are increasingly common worldwide. Patients with associated spinal cord injury have a high morbidity due to associated injuries and require prolonged in-hospital treatment and rehabilitation.

Current literature is aimed at the treatment of ballistic injuries sustained in war, and few studies pertain to civilian gunshot injuries of the spinal column and their treatment. If the treatment protocol of wartime injuries is applied, it would add to the already massive cost burden associated with these patients, without much added benefit.
From the literature it is clear that most injuries are stable, and can be treated by conservative means. Lead poisoning is extremely rare, and thus not an indication for routine bullet removal.

The only indications for removal of retained bullet fragments would be: progressive neurological deterioration, sepsis, lead poisoning and retained fragments between T12 and L4 with incomplete neurological injury.

Routine irrigation and removal of the bullet fragments that traverse the abdomen is not necessary, unless the intra-abdominal injury warrants exploration.

Duration of prophylactic antibiotic treatment has also been reduced, and spinal sepsis is an uncommon occurrence. Cases of spinal sepsis occurred even in those patients that had extended periods of prophylactic antibiotics.

In conclusion the surgical management of civilian gunshot injuries to the spinal column should be reserved for selected cases only. The majority of injuries are managed conservatively, but close scrutiny should be given for associated injuries, many of which will need surgical intervention.

\section{Compliance with Ethics Guidelines}

A Botha, RN Dunn and C Booysen have no conflict of interest to declare, and the work is solely that of the authors.

\section{References}

1. Police have 'lost' 20429 weapons. Die Burger. (Accessed 9 March, 2011,

2. Saadia R. Organisation of hospital responses for the trauma epidemic. British Medical Bulletin 1999;55:767-84.

3. Le Roux JC, Dunn RN. Gunshot injuries of the spine-a review of 49 cases managed at the Groote Schuur Acute Spinal Cord Injury Unit. S Afr J Surg 2005;43:165-68.

4. Chamisa I. Civilian abdominal gunshot wounds in Durban, South Africa: a prospective study of 78 cases. Annals of the Royal College of Surgeons of England 2008;90:581.

5. Carrillo EH, Gonzalez JK, Carrillo LE, et al. Spinal cord injuries in adolescents after gunshot wounds: an increasing phenomenon in urban North America. Injury 1998;29:503-507.

6. Sidhu GS, Ghag A, Prokuski V, Vaccaro AR, Radcliff KE. Civilian gunshot injuries of the spinal cord: a systematic review of the current literature. Clin Orthop Relat Res 2013;471:3945-55.

7. Farmer JC, Vaccaro AR, Balderston RA, Albert TJ, Cotler J. The changing nature of admissions to a spinal cord injury center: violence on the rise. Journal of Spinal Disorders $\mathcal{E}$ Techniques 1998;11:400-403.

8. Isiklar Z, Lindsey R. Low-velocity civilian gunshot wounds of the spine. Orthopedics 1997;20:967-72.

9. Isiklar ZU, Lindsey RW. Gunshot wounds to the spine. Injury 1998;29 Suppl 1:SA7-12.

10. Isiklar ZU, Lindsey RW. Low-velocity civilian gunshot wounds of the spine. Orthopedics 1997;20:967-72. 
11. Bono CM, Heary RF. Gunshot wounds to the spine. Spine 2004;4:230-40.

12. Prewitt TF. III. Gunshot Injuries of the Spine, with Report of a Case. Ann Surg 1898;28:187-215.

13. Heiden JS, Weiss MH, Rosenberg AW, Kurze T, Apuzzo ML. Penetrating gunshot wounds of the cervical spine in civilians. Review of 38 cases. J Neurosurg 1975;42:575-79.

14. Gordon DS. Surgery of violence. V. Missile wounds of the head and spine. Br Med J 1975;1:614-16.

15. Stauffer ES, Wood RW, Kelly EG. Gunshot wounds of the spine: the effects of laminectomy. J Bone Joint Surg Am 1979;61:389-92.

16. Schaefer SD, Bucholz RW, Jones RE, Carder HM. The management of transpharyngeal gunshot wounds to the cervical spine. Surg Gynecol Obstet 1981;152:27-29.

17. Waters RL. Gunshot wounds to the spine: the effects of bullet fragments in the spinal canal. J Am Paraplegia Soc 1984;7:30-33.

18. Benzel EC, Hadden TA, Coleman JE. Civilian gunshot wounds to the spinal cord and cauda equina. Neurosurgery 1987;20:281-85.

19. Gellad FE, Paul KS, Geisler FH. Early sequelae of gunshot wounds to the spine: radiologic diagnosis. Radiology 1988;167:523-26.

20. Simpson RK, Jr., Venger BH, Fischer DK, Narayan RK, Mattox KL. Shotgun injuries of the spine: neurosurgical management of five cases. Br J Neurosurg 1988;2:321-26.

21. Wigle RL. Treatment of asymptomatic gunshot injuries to the spine. Am Surg 1989;55:591-95.

22. Roffi RP, Waters RL, Adkins RH. Gunshot wounds to the spine associated with a perforated viscus. Spine (Phila Pa 1976) 1989;14:808-11.

23. Cybulski GR, Stone JL, Kant R. Outcome of laminectomy for civilian gunshot injuries of the terminal spinal cord and cauda equina: review of 88 cases. Neurosurgery 1989;24:39297.

24. Kupcha PC, An HS, Cotler JM. Gunshot wounds to the cervical spine. Spine (Phila Pa 1976) 1990;15:1058-63.

25. Jancovici R, Jourdan P, Mianne D, Naudan P, Brissiaud JC, Pailler JL. [Multiple wounds caused by a $5.56 \mathrm{~mm}$ bullet: the Famas, a competitive weapon]. J Chir (Paris) 1987;124:515-19.

26. Parsons TW, 3rd, Lauerman WC, Ethier DB, et al. Spine injuries in combat troops-Panama, 1989. Mil Med 1993;158:501-502.

27. Kang DG, Lehman RA, Jr., Bevevino AJ, Bernstock JD. Large caliber ballistic fragment within the spinal canal. Spine J 2012;12:869-70.

28. Blair JA, Patzkowski JC, Schoenfeld AJ, et al. Spinal column injuries among Americans in the global war on terrorism. J Bone Joint Surg Am 2012;94:e135(1-9).

29. Schoenfeld AJ, Dunn JC, Belmont PJ. Pelvic, spinal and extremity wounds among combat-specific personnel serving in Iraq and Afghanistan (2003-2011): A new paradigm in military musculoskeletal medicine. Injury 2013;44:1866-70.

30. Schoenfeld AJ, Laughlin MD, McCriskin BJ, Bader JO, Waterman BR, Belmont PJ, Jr. Spinal injuries in United States military personnel deployed to Iraq and Afghanistan: an epidemiological investigation involving 7877 combat casualties from 2005 to 2009. Spine (Phila Pa 1976) 2013;38:1770-78.
31. Schoenfeld AJ, Newcomb RL, Pallis MP, et al. Characterization of spinal injuries sustained by American service members killed in Iraq and Afghanistan: a study of 2,089 instances of spine trauma. J Trauma Acute Care Surg 2013;74:1112-18.

32. Greer LT, Kuehn RB, Gillespie DL, et al. Contemporary management of combat-related vertebral artery injuries. $J$ Trauma Acute Care Surg 2013;74:818-24.

33. Rivera JC, Anderson ER, Jenne JW, Topp RF. Spine-related disability following combat injury. J Surg Orthop Adv 2014;23:136-39.

34. DeVivo MJ, Stover SL, Black KJ. Prognostic factors for 12year survival after spinal cord injury. Archives of Physical Medicine and Rehabilitation 1992;73:156-62.

35. Matson DD. Treatment of compound spine injuries in forward army hospitals. Journal of Neurosurgery 1946;3:114-19.

36. Haynes WG. Acute war wounds of the spinal cord: Analysis of 184 cases. The American Journal of Surgery 1946;72:424-33.

37. Bartlett CS, Helfet DL, Hausman MR, Strauss E. Ballistics and gunshot wounds: effects on musculoskeletal tissues. Journal of the American Academy of Orthopaedic Surgeons 2000;8:21-36.

38. Bumpass DB, Buchowski JM, Park A, et al. An update on civilian spinal gunshot wounds: treatment, neurological recovery, and complications. Spine (Phila Pa 1976) 2015;40:450-61.

39. Teitelbaum GP, Yee C, Van Horn D, Kim H, Colletti P. Metallic ballistic fragments: MR imaging safety and artifacts. Radiology 1990;175:855-59.

40. Shellock F, Curtis JS. MR imaging and biomedical implants, materials, and devices: an updated review. Radiology 1991;180:541-50.

41. Shellock F. MR imaging of metallic implants and materials: a compilation of the literature. American Journal of Roentgenology 1988;151:811-14.

42. Eshed I, Kushnir T, Shabshin N, Konen E. Is magnetic resonance imaging safe for patients with retained metal fragments from combat and terrorist attacks? Acta Radiologica 2010;51:170-74.

43. Dedini RD, Karacozoff AM, Shellock FG, Xu D, McClellan RT, Pekmezci M. MRI issues for ballistic objects: information obtained at 1.5-, 3- and 7-Tesla. Spine J 2013;13:815-22.

44. Grogan DP, Bucholz RW. Acute lead intoxication from a bullet in an intervertebral disc space. A case report. J Bone Joint Surg Am 1981;63:1180-2.

45. Linden MA, Manton WI, Stewart RM, Thal ER, Feit H. Lead poisoning from retained bullets. Pathogenesis, diagnosis, and management. Ann Surg 1982;195:305-13.

46. Tindel NL, Marcillo AE, Tay BK, Bunge RP, Eismont FJ. The effect of surgically implanted bullet fragments on the spinal cord in a rabbit model. J Bone Joint Surg Am 2001;83A:884-90.

47. Scuderi GJ, Vaccaro AR, Fitzhenry LN, Greenberg S, Eismont F. Long-term clinical manifestations of retained bullet fragments within the intervertebral disk space. $J$ Spinal Disord Tech 2004;17:108-11.

48. Cristante AF, de Souza FI, Barros Filho TE, Oliveira RP, Marcon RM. Lead poisoning by intradiscal firearm bullet: a case report. Spine (Phila Pa 1976) 2010;35:E140-43. 
49. Rentfrow B, Vaidya R, Elia C, Sethi A. Lead toxicity and management of gunshot wounds in the lumbar spine. Eur Spine J 2013;22:2353-57.

50. Levy ML, Gans W, Wijesinghe HS, SooHoo WE, Adkins $\mathrm{RH}$, Stillerman CB. Use of methylprednisolone as an adjunct in the management of patients with penetrating spinal cord injury: outcome analysis. Neurosurgery 1996;39:1141-8; discussion 8-9.

51. Heary RF, Vaccaro AR, Mesa JJ, et al. Steroids and gunshot wounds to the spine. Neurosurgery 1997;41:576-83; discussion 83-84.

52. Waters RL, Adkins RH. The effects of removal of bullet fragments retained in the spinal canal. A collaborative study by the National Spinal Cord Injury Model Systems. Spine (Phila Pa 1976) 1991;16:934-39.

53. Waters RL, Adkins RH, Yakura J, Sie I. Profiles of spinal cord injury and recovery after gunshot injury. Clinical orthopaedics and related research 1991;267:14-21.

54. Waters RL, Sie I, Adkins RH, Yakura JS. Injury pattern effect on motor recovery after traumatic spinal cord injury. Arch Phys Med Rehabil 1995;76:440-43.

55. Waters RL, Adkins RH, Yakura JS, Sie I. Effect of surgery on motor recovery following traumatic spinal cord injury. Spinal Cord 1996;34:188-92.

56. Waters RL, Sie IH. Spinal cord injuries from gunshot wounds to the spine. Clin Orthop Relat Res 2003:120-25.
57. Robertson DP, Simpson RK. Penetrating injuries restricted to the cauda equina: a retrospective review. Neurosurgery 1992;31:265-9; discussion 9-70.

58. Romanick PC, Smith TK, Kopaniky DR, Oldfield D. Infection about the spine associated with low-velocitymissile injury to the abdomen. J Bone Joint Surg Am 1985;67:1195-201.

59. Kihtir T, Ivatury RR, Simon R, Stahl WM. Management of transperitoneal gunshot wounds of the spine. J Trauma 1991;31:1579-83.

60. Lin SS, Vaccaro AR, Reisch S, Devine M, Cotler JM. Lowvelocity gunshot wounds to the spine with an associated transperitoneal injury. J Spinal Disord 1995;8:136-44.

61. Kumar A, Wood GW, 2nd, Whittle AP. Low-velocity gunshot injuries of the spine with abdominal viscus trauma. J Orthop Trauma 1998;12:514-17.

62. Rabinowitz RP, Tabatabai A, Stein DM, Scalea TM. Infectious complications in GSW's through the gastrointestinal tract into the spine. Injury 2012;43:1058-60.

This article is also available online on the SAOA website (www.saoa.org.za) and the SciELO website (www.scielo.org.za). Follow the directions on the Contents page of this journal to access it. 